\title{
Lukisan Pemandangan: Teknik Spon Dalam Karya Seni Lukis Jelekong
}

\author{
Shopia Himatul Alya \\ Program Studi Seni Rupa Murni Universitas Kristen Maranatha \\ J1. Surya Sumantri 65 Bandung-40164 \\ shopiaalya13@gmail.com / 0857-5933-7319
}

Received: 02 Oktober 2020; Revised: 21 November 2020; Accepted: 28 Desember 2020

DOI: http://dx.doi.org/10.37905/aksara.7.1.103-110.2021

\begin{abstract}
Nature is a theme that is always present in the development of art in the world, both Western and Asian arts, such as China and Indonesia. The visualization can be a literal or abstract representation. Nature can be an additional element to a painting to convey depth, or perspective. However, the depiction of nature in a painting can also be the main focus of a work of art. In Indonesia itself, there is an Art Village, precisely Jelekong Art Village, where hundreds of people work as painters and some have made nature the main focus of their work. The uniqueness of the Jelekong painter's work lies in the method used and the materials used. So that the authors are interested in further researching the uniqueness of this Jelekong technique. The purpose of this research is to examine the comparison of natural visualization techniques and aspects of Jelekong painting which represent nature in terms of methods and materials. The samples in this study were paintings by Jelekong artists and Western artists. The qualitative descriptive method is considered the most appropriate for analyzing Jelekong painting. The result of this research is that the superiority of the art technique of Ugong painting is the sponge technique created by one of its residents. This technique can create shadow, middle tone, and highlight in a painting. Jelekong's paintings can become the identity of the community in cultivating the local potential of the region
\end{abstract}

Keywords: Jelekong Painting; Landscape Painting, Technique; Uniqueness

\section{PENDAHULUAN}

\section{Desa Jelekong}

Jelekong adalah sebuah Desa di jawa barat yang lokasinya terletak di Kecamatan Baleendah Kabupaten Bandung. Wilayah ini terkenal sebagai sentra seni lukis Jelekong (diambil dari nama wilayahnya). Karya seni lukis yang dihasilkan oleh penduduknya memiliki keistimewaan mengangkat tema pemandangan. Karya seni lukis yang dihasilkan pernah booming dan mengalami masa kejayaan dari sisi penjualan. Berbagai daerah dan pesanan dari daerah wisata di Indonesia mengalir deras. Tidak heran apabila penduduknya pada masa tersebut banyak yang beralih profesi dari mengerjakan sawah atau berdagang menjadi pelukis yang ditularkan dari para seniornya (Sukapura Dewi et al., 2008). 
Volume : 07

Nomor : 01

Bulan : Januari

Tahun : 2021

http://ejurnal.pps.ung.ac.id/index.php/AKSARA/index

\section{Tema Pemandangan Alam}

Gagasan yang berasal dari alam merupakan tema yang selalu hadir dalam perkembangan seni rupa di dunia baik seni rupa Barat maupun Asia, seperti China dan Indonesia. Visualisasinya pun bisa berupa representasi literal maupun abstrak. Alam bisa menjadi elemen tambahan pada lukisan untuk menyampaikan kedalaman, atau perspektif. Alam yang divisualisasikan ke dalam lukisan juga bisa menjadi fokus utama sebuah karya seni. Di Indonesia sendiri, terdapat sebuah Kampung Seni tepatnya Kampung Seni Jelekong di mana ratusan orang berprofesi sebagai pelukis dan sebagian menjadikan alam sebagai fokus utama dalam karya mereka. Keunikan dari karya para pelukis Jelekong terdapat pada metoda yang digunakan serta material yang digunakan. Keunikan-keunikan ini menjadi daya tarik tersendiri dari seni lukis Jelekong pada umumnya.

Visualisasi karya seni lukis dengan tema pemandangan alam pada seni lukis Jelekong tidak lain berasal dari dorongan seniman untuk merepresentasikan alam sekitar seperti keindahan hamparan padi di tengah sawah, keindahan gunung-gunung, sejuknya air terjun yang mengalir deras di tengah pohon yang rimbun. Tema tema lukisan yang mengusung gagasan dari alam tidak hanya dijumpai di jelekong saja. Beberapa seniman besar juga terinspirasi dengan karya seni lukis pemandangan. Khusunya dari penelusuran sejarah juga terekam data bahwa Wakidi salah satu seorang seniman dari Indonesia yang karya seni lukisnya banyak memvisualisasikan gemericik air sungai yang mengalir diselasela batu, rimbunnya pepohonan, sehingga demikian terasa ketika orang mengapresiasi karya seni lukisnya (Pandanwangi et al., 2019). Sedangkan seniman dari barat yang juga mengusung lukisan pemandangan adalah John Constable, Thomas Cole, adalah beberapa contoh seniman dari barat yang mengusung tema pemandangan sekaligus merespon situasional pada masa nya (Kleiner, 2014).

\section{Teknik Spon}

Teknik spon adalah teknik yang tercipta dari eksperimen salah satu pelukis ternama dari Jelekong yang bernama Bapak Kusmana. Teknik ini sukses memberikan identitas khas terhadap seni lukis Jelekong yang fokus utamanya adalah penggambaran keindahan alam. Teknik visualisasi elemen alam pada seni lukis Jelekong ini yang menjadi pemicu melonjaknya jumlah pelukis di Jelekong. Teknik spon, ini menjadi menarik karena menggunakan spon (karet busa) yang diiris kemudian dipergunakan dalam membuat lukisan naturalis (Sukapura Dewi et al., 2008). Teknik Spon ini memudahkan apresiator untuk mengenali karya-karya yang dihasilkan oleh para pelukis Jelekong karena memiliki karakter yang berbeda dengan karya-karya yang dihasilkan olehseniman Barat bahkan oleh seniman Indonesia beraliran mooi indie (Hindia Molek) yang populer pada abad ke19.

Permasalahan yang diangkat dalam penelitian ini adalah bagaimana komparasi lukisan dari Jelekong dan karya seni lukis dari Barat dari segi teknik yang mengusung tema pemandangan. Permasalahan ini diusung karena menurut penulis menjadi krusial karena dari sisi teknik lukisan Jelekong juga memiliki keistimewaan tidak kalah dari lukisan di barat dari sisi teknis. Untuk memecahkan permasalahan dalam penelitian ini maka dibutuhkan metoda deskriptif kualitatif yaitu sebuah metode yang mendeskripsikan data yang diperoleh dari lapangan baik berupa wawancara ataupun observasi serta rekaman berbaga data (Sumartono, 2017). Data juga diperoleh dari berbagai rujukan penelitian terdahulu ataupun studi literatur. Teknik pengumpulan data dalam penelitian 
ini menggunakan teknik pengumpulan data wawancara (interview) secara virtual, yaitu cara untuk mendapatkan dan atau mengumpulkan informasi dan data penelitian dengan melakukan tanya jawab kepada informan yang berhubungan dengan objek penelitian (Creswell, 2014). Selain itu juga dibutuhkan studi lapangan, yaitu mengumpulkan informasi dan data dengan cara terjun ke lapangan dalam proses penelitian. Sampel dalam penelitian ini berupa karya seni lukis jelekong yang diambil dari data lapangan, sedangkan lukisan dari Barat dengan tema pemandangan diperoleh dari studi literature yang berhasil didapatkan dari penelusuran sejarah yang merekam jejak lukisan dengan tema pemandangan.

Penelitian ini bertujuan untuk mengkaji teknik melukis Spon yang digunakan oleh para pelukis di Jelekong dalam merepresentasikan pemandangan alam ke dalam sebuah karya, mengkaji perbandingan visualisasi alam dalam seni rupa Jelekong dan seni rupa Barat serta menggali keanekaragaman teknik seni rupa yang unik di ranah seni rupa tradisional Jelekong.

\section{PEMBAHASAN}

Beberapa penelitian terdahulu yang mengupas tentang desa jelekong adalah (Sukapura Dewi et al., 2008) penelitiannya membahas karya-seni rupa Jelekong yang dapat meningkatkan potensi kepariwisataan. Karya yang dibahas berdasarkan periode 1969-2007. Metode dalam penelitian tersebut digunakan deskriptif kualitatif. Hasil dari penelitian tersebut wilayah jelekong memiliki keunggulan untuk terus meningkatkan ekonomi rakyatnya melalui karya seni lukis rakyat. Keunggulan ini tidak dimiliki daerah lain di Jawa barat. Tantangannya adalah bagaimana pemerintah daerah bekerjasama dengan pelaku industri dari biro perjalanan.

Peneliti lain adalah (Setiawan, 2012) membahas tentang Kampung Seni Jelekong yang masyarakatnya berbasis industry kreatif serta mampu membentuk kebudayaannya melalui karya seni lukis yang dihasilkannya. Metode yang dipilihnya adalah metode deskripsi dengan pendekatan kualitatif. Penelitian ini menemukan bahwa ini terbentuknya eksistensi masyarakat ini berkat adanya ketekunan, strategi pemasaran, serta pembagian kerja yang disepakati bersama.

Penelitian tersebut di atas difokuskan pada kepentingan peningkatan kepariwisataan dan adanya babsis industry kreatif yang terbentuk dari pola-pola hidup masyarakat yang mengutamakan ketekunan dan gotong royong.

\section{Lukisan Jelekong.}

Visualisasi pemandangan Alam oleh para pelukis Jelekong telah menciptakan sebuah kualitas estetik yang khas seperti padi yang menguning, gotong-royong para petani, pedati serta sungai yang biru dalam lukisan panen. Atau pepohonan hijau nan sejuk yang rimbun, air terjun yang indah, rusa-rusa di dekat sungai serta bebatuan dalam lukisan pemandangan air terjun. Tak lupa, penampakan rumah-rumah khas zaman dahulu, orang-orang kampung yang beraktifitas, sungai yang bersih, rerumputan yang hijau, pohon bambu serta jembatan dari bambu dalam lukisan pemandangan alam perkampungan. 


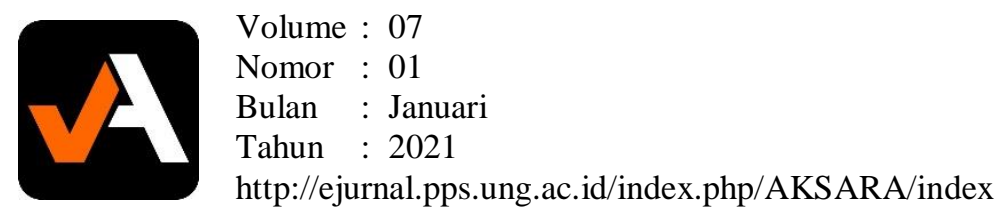

\section{Perbandingan Visualisasi Keindahan Alam Pada Seni Rupa Jelekong Dan Seni Rupa Barat}

Perbandingan antara penggambaran alam dalam seni rupa Jelekong serta seni rupa Barat dapat ditelaah melalui konsep representasi dan interpretasi. Dalam seni rupa Barat, penggambaran gunung yang realistis misalnya dapat melambangkan keluhuran, tetapi juga keingintahuan akan hal yang tidak diketahui. Penggambaran alam dalam seni rupa Barat juga dapat dimaknai sebagai pemikiran intelektual dan spiritualitas. Dalam hal ini, visualisasi alam ke dalam karya dua dimensi dalam seni rupa Barat tidak hanya menampilkan keindahan alam, namun untuk membuka pikiran kita terhadap gagasan filosofis tentang hubungan manusia dengan alam juga. Selain itu, representasi alam dalam seni rupa Barat lebih luas daripada representasi alam dalam seni rupa Jelekong.

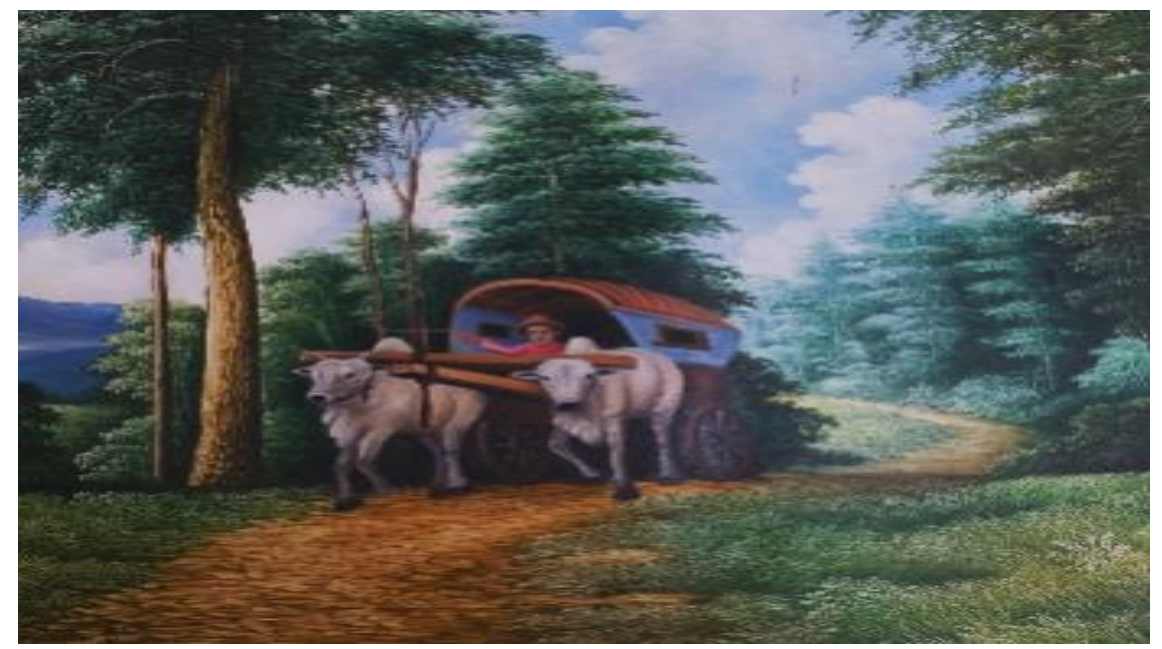

Gambar 1. Contoh Visualisasi Alam Sumber: Dokumentasi Penulis. 2020

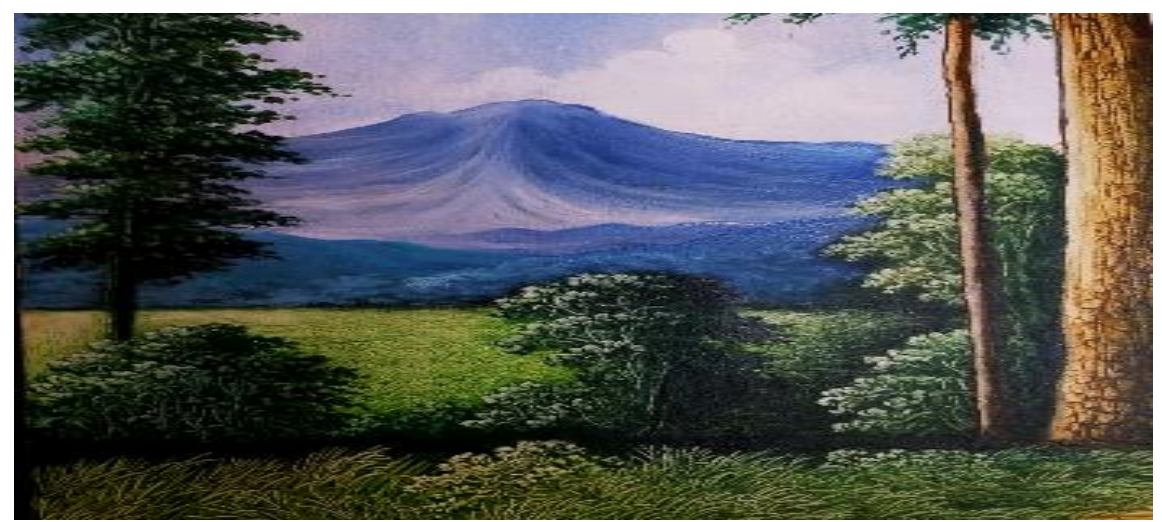

Gambar 2. Contoh Visualisasi Alam Sumber: Dokumentasi Penulis. 2020

Dalam seni rupa Barat, menurut (Indrobo, 2012), alam dapat dimaknai sebagai pengalaman seperti dalam karya Caspar David Friedrich "Wanderer above the Sea of Fog (German: Der Wanderer über dem Nebelmeer)", bahan mentah seperti dalam karya Robert Smithson and Richard Long "Spiral Jetty". Dalam kata lain, nature atau yang dalam bahasa Indonesia berarti alam, dalam seni rupa Barat tidak dapat ditafsirkan sebagai makna tunggal karena cakupannya yang luas sekali. Pada seni rupa Jelekong, 
visualisasi alam juga tidak hanya berkutat pada urusan menampilkan keindahan alamnya saja. Karya seni lukis Jelekong dan karya lukis Barat memiliki kesamaan di mana karya mereka tidak hanya memuat gagasan filosofis tentang hubungan manusia dengan alam namun hubungan manusia dengan manusia. Hal yang menjadi pembeda ialah pada konsep representasi dan interpretasi di mana karya seni Jelekong merepresentasikan kebenaran yang para pelukis saksikan di sekitar mereka.

Penafsiran karya seni lukis Jelekong pun sangat gamblang dan sederhana karena karya mereka merupakan refleksi dari keindahan alam. Kemudian gagasan filosofis hubungan manusia dengan alam serta manusia dengan manusia pun merupakan sebuah tafsiran yang kebanyakan berasal dari penanggap atau penggemar karya seni Jelekong. Pada dasarnya, para pelukis Jelekong hanya merefleksikan atau merepresentasikan keindahan alam. Menurut (Julisa et al., 2019) upaya partisipasi masyarakat dapat menjadi model dalam meningkatkan industri kreatif dan sekaligus meningkatkan kenyamanan bagi lingkungannya. Lukisan pemandangan bagi apresiator sehingga dianggap menarik karena dapat dianggap merepresentasikan sebuah tempat yang indah (Balik \& Balik Lökçe, 2019).

\section{Teknik Visualisasi Pemandangan Alam Dalam Lukisan Jelekong}

Istilah spon merujuk pada kata sponge dalam bahasa inggris yang berarti spons. Teknik spon merupakan sebuah teknik yang pertama kali dikenalkan oleh seniman senior Jelekong, Kusmana, dan masih terus dipelajari dan disebarkan sampai saat ini. Sedari awal teknik ini dikenalkan, perkembangan jumlah pelukis dengan spesialisasi lukisan spon kian bertambah dengan sebuah cara yang unik. Contohnya adalah salah satu proses penyebaran teknik spon yang terjadi sekitar tahun 95an ketika salah seorang pelukis spon yang sudah mahir dalam teknik ini bisa memiliki kurang lebih 10 murid di rumah tempatnya bekerja. Kesepuluh murid tersebut dapat dikatakan sebagai pekerja 'magang'. Hal demikian kemudian terus-menerus berulang dengan kemauan salah satu murid atau bahkan lebih yang kemudian menyebarkan ilmu yang didapat pada murid-murid yang lain dan begitu seterusnya.

Teknik spon adalah teknik yang sangat popular karena pemakaian alat uniknya. Material tersebut di antaranya adalah potongan karet dari sandal jepit bekas yang tak terpakai, spon atau karet busa yang biasa diambil dari sofa yang sudah tak terpakai lagi dimakan usia. Alat yang dipakai yang notabene bekas inilah yang bisa menarik perhatian pengunjung, penikmat seni, dan kalangan akademisi sekalipun. Keunikan teknik spon ialah terdapat pada material yang digunakan serta teknik yang digunakan. Pertama, pelukis akan membuat lapisan pertama atau latar belakang yang disebut dengan proses ngalataran. Kedua, spon dimanfaatkan untuk menciptakan shadow, middle tone, serta higlight daripada karya tersebut. Efek yang dihasilkan dari karya seni lukis dengan teknik spon ini dapat menjadi identitas sebuah daerah yang mngangkat potensi lokalnya (Perbawasari et al., 2019).

Spon digunakan untuk menghapus cat yang ditambahkan sewaktu proses ngalataran. Ketiga, proses nyoret di mana pembuatan motif di mana visualisasi dari rumput, padi, pohon dan sebagainya dilakukan menggunakan sebuah karet bekas yang sering kita temui di dalam sandal jepit yang telah dibentuk sedemikian rupa menyerupai pensil. 


$$
\begin{aligned}
& \text { Volume : } 07 \\
& \text { Nomor : } 01 \\
& \text { Bulan : Januari } \\
& \text { Tahun : } 2021 \\
& \text { http://ejurnal.pps.ung.ac.id/index.php/AKSARA/index }
\end{aligned}
$$

\section{PENUTUP}

Kampung Seni Jelekong memiliki potensi yang besar berupa keragaman aliran seni rupa yang berangkat dari kearifan lokal masyarakatnya. Hal ini didukung oleh keadaan sumber daya alam, sumber daya manusia, fisik dan sosial budaya di Kampung Seni Jelekong yang banyak memberikan kontribusi untuk keberlangsungan preservasi seni dan budaya di Jelekong. Eksistensi seni lukis Jelekong, tema yang diangkat pada umumnya adalah keindahan alam yang

mengingatkan pada periode Mooi Indie di abad ke-19 saat perkembangan seni lukis di Indonesia dimana pemandangan alam yang indah banyak diangkat dan dinikmati ke dalam tema karya seni lukis. Dan tema-tema tersebut justru menjadi kekuatan bagi seni rupa Jelekong. Seni rupa Barat dan seni rupa Jelekong dalam hal merepresentasikan alam memiliki beberapa

perbedaan yang mana perbedaan tersebut terletak pada konsep karya keduanya. Alam dapat dimaknai secara beragam dalam seni rupa Barat karena cakupannya yang luas. Namun dalam seni rupa Jelekong, penafsiran karya lukis pemandangan cukup mudah dan gamblang karena para pelukis hanya merefleksikan kualitas keindahan alamnya dan diolah dengan standar ideal

yang tercipta dalam lingkup seni rupa Jelekong.

\section{DAFTAR PUSTAKA}

Balik, G., \& Balık Lökçe, D. (2019). On the Relationship of Landscape and Painting. AM Journal of Art and Media Studies, 19, 29-44. https://doi.org/10.25038/am.v0i19.305

Creswell, J. W. (2014). Penelitian Kualitatif dan Desain Riset. Pustaka Pelajar. Indrobo, C. (2012). He Who Is Leaving ... The Figure of the Wanderer in Nietzsche's Also sprach Zarathustra and Caspar David Friedrich's Der Wanderer über dem Nebelmeer. Nietzsche-Studien, 41(1). https://doi.org/https://doi.org/10.1515/niet.2012.41.1.78

Julisa, J., Parjito, P., \& Putra, D. F. (2019). Persepsi Dan Partisipasi Masyarakat Kawasan Kampung Warna-Warni Terhadap Upaya Perbaikan. JPIG (Jurnal Pendidikan Dan Ilmu Geografi), 4(1), 26-40. https://doi.org/10.21067/jpig.v4i1.3108

Kleiner, F. S. (2014). Gardner's Art Through The Ages: A Concisw Western History. In S. A. Poore (Ed.), Wadsworth, Cengage Learning, USA (Third Edit). Wadsworth, Cengage Learning.

Pandanwangi, A., Sukapura Dewi, B., \& Elnissi Tanok, S. (2019). Komparasi Karya Seni Lukis Mooi Indie antara Seniman Indonesia dan Seniman dari Barat Periode 1930-an. Budaya Nusantara, 2(2), 305-311. https://doi.org/https://doi.org/10.36456/b.nusantara.vol2.no2.a1968

Perbawasari, S., Dida, S., \& Nugraha, A. R. (2019). Peran stakeholders dalam membangun identitas Purwakarta yang berwawasan nilai budaya lokal. PRofesi Humas Jurnal Ilmiah Ilmu Hubungan Masyarakat, 4(1), 23. https://doi.org/10.24198/prh.v4i1.21349

Setiawan, I. (2012). The Existence of Jelekong Art Village in Supporting Household Needs. Patanjala, 4(2), 58-73.

https://doi.org/http://dx.doi.org/10.30959/patanjala.v4i2.140

Sukapura Dewi, B., Pandanwangi, A., \& Prasetya, S. (2008). Kajian Seni Rupa 
Volume : 07

Nomor : 01

Bulan : Januari

Tahun : 2021

http://ejurnal.pps.ung.ac.id/index.php/AKSARA/index

Jelekong, Bale Endah Bandung Meningkatkan Potensi Kepariwisataan Jawa Barat.

https://www.researchgate.net/publication/277735035_Kajian_Seni_Rupa_Jelekong _Bale_Endah_Bandung_Meningkatkan_Potensi_Kepariwisataan_Jawa_Barat

Sumartono. (2017). Metodologi Penelitian Kualitatif: Seni Rupa. Universitas Trisakti.. 